\title{
Pulp tissue dissolution when the use of sodium hypochlorite and EDTA alone or associated
}

\author{
Dissolução do tecido pulpar quando do uso do \\ hipoclorito de sódio e EDTA isoladamente ou associados
}

\begin{abstract}
Purpose: The aim of the present study was to evaluate the tissue dissolving capacity of various concentrations of sodium hypochlorite either alone or in combination with 17\% EDTA.

Methods: Eighty bovine pulp fragments were prepared, and their weight was determined using a precision balance. Each pulp fragment was immersed for 2 hours in a solution/mixture that was based on the following groups: $\mathrm{G} 1$ - saline solution; $\mathrm{G} 2-0.5 \% \mathrm{NaOCl} ; \mathrm{G} 3-1.0 \% \mathrm{NaOCl}$; G4 $-2.5 \% \mathrm{NaOCl}$; G5 - 17\% EDTA; G6 - 0.5\% NaOCl+ 17\% EDTA; G7 - 1.0\% NaOCl+ $17 \%$ EDTA; and G8 $-2.5 \% \mathrm{NaOCl}+17 \%$ EDTA. The final weight was measured, and the weight loss was calculated. A statistical analysis was performed using either the Student's t-test for paired samples or an ANOVA and Tukey tests ( $P<0.05$ was considered to be significant). Results: We measured a significant difference between the sample weight before and after treatment for each of the tested groups $(P<0.05)$. The $2.5 \%$ sodium hypochlorite solution $(G 4)$ completely dissolved the pulp tissue within the test period. $\mathrm{NaOCl}+\mathrm{EDTA}$ was less effective than sodium hypochlorite alone at dissolving the pulp tissue $(P<0.05)$, and EDTA alone $(G 5)$ did not markedly dissolve the pulp tissue.
\end{abstract}

Conclusion: Using EDTA together with $\mathrm{NaOCl}$ reduced the tissue dissolving properties compared with $\mathrm{NaOCl}$ alone, regardless of the concentration of $\mathrm{NaOCl}$ that was used.

Key words: Sodium hypochlorite; EDTA; pulp tissue; endodontics

\section{Resumo}

Objetivo: $O$ objetivo do presente estudo foi avaliar a capacidade de dissolução tecidual de várias concentrações de hipoclorito de sódio, isoladamente ou em combinação com o EDTA $17 \%$.

Metodologia: Oitenta fragmentos de polpa bovina foram preparados e seus pesos foram determinados através de uma balança de precisão. Cada fragmento pulpar foi imerso por 2 horas em cada uma das soluções/misturas e formaram os seguintes grupos: G1 - Solução salina; G2- $\mathrm{NaOCl} 0,5 \%$; G3- $\mathrm{NaOCl} 1 \%$; G4- $\mathrm{NaOCl} 2,5 \%$; G5- EDTA 17\%; G6- $\mathrm{NaOCl}$ $0,5 \%$ + EDTA 17\%; G7- NaOCl 1,0\% + EDTA 17\%; G8- NaOCl 2,5\% + EDTA 17\%. O peso final foi medido e a perda de peso calculada. A análise estatística foi realizada através do teste $t$ de Student para amostras pareadas, ou ANOVA e teste de Tukey.

Resultados: Verificaram-se diferenças entre os pesos das amostras antes e depois do tratamento para cada um dos grupos testados $(P<0,05)$. A solução de hipoclorito de sódio $2,5 \%(G 4)$ dissolveu completamente o tecido pulpar dentro do período teste. $O$ hipoclorito de sódio + EDTA foi menos efetivo na dissolução do tecido pulpar do que o hipoclorito de sódio sozinho $(P<0,05)$, e o EDTA (G5) não dissolveu o tecido pulpar.

Conclusão: O uso do EDTA misturado com o hipoclorito de sódio reduziu a propriedade de dissolução tecidual comparado ao hipoclorito de sódio sozinho, a despeito das concentrações de hipoclorito de sódio.

Palavras-chave: Hipoclorito de sódio; EDTA; tecido pulpar; endodontia

\author{
Marcus Vinícius Reis Só a \\ Fabiana Vieira Vier-Pelisser ${ }^{b}$ \\ Mirena Sonza Darcie c \\ Daniele Geni Rockenbach Smaniotto c \\ Francisco Montagner a \\ Milton Carlos Kuga d
}

\begin{abstract}
a Department of Endodontics, Federal University of Rio Grande do Sul, Porto Alegre, RS, Brazil b Endodontics Division, Pontifical Catholic University of Rio Grande do Sul, Porto Alegre, RS, Brazil c Cruzeiro do Sul University, Caxias do Sul, RS, Brazil

${ }^{d}$ Department of Restorative Dentistry, Araraquara Dental School, São Paulo State University (UNESP), Araraquara, SP, Brazil
\end{abstract}

\author{
Correspondence: \\ Marcus Vinicius Reis Só \\ Universidade Federal do Rio Grande do Sul \\ Rua Souza Lobo 62 casa 03 \\ Porto Alegre, RS - Brasil \\ 91320-320 \\ E-mail: endo-so@hotmail.com
}

Received: January 22, 201

Accepted: April 7, 2011

Conflict of Interest Statement: The authors state that there are no financial and personal conflicts of interest that could have inappropriately influenced their work.

Copyright: (C) 2011 Só et al.; licensee EDIPUCRS. This is an Open Access article distributed under the terms of the Creative Commons AttributionNoncommercial-No Derivative Works 3.0 Unported License. 


\section{Introduction}

Several different techniques and substances are commonly used to clean and shape the root canal system. At least 35\% of the walls of the root canal are not reached using files and rotary instruments after chemomechanical preparation (1). The use of an auxiliary chemical substance can improve root canal debridement, thereby promoting the removal of tissue debris and microorganisms (2-3).

Sodium hypochlorite $(\mathrm{NaOCl})$ is widely used to irrigate the root canal in endodontic procedures. The properties of $\mathrm{NaOCl}$ are based on the solution's concentration, temperature and $\mathrm{pH}(4-5)$. $\mathrm{NaOCl}$ has low superficial tension (6) and has antimicrobial action (7), the ability to reduce endotoxic load (8), and the capacity to dissolve organic tissue (9-10). Só et al. (9), Spanó et al. (11) and Okino et al. (12) reported that high concentrations of $\mathrm{NaOCl}$ rapidly dissolve tissue.

Although $\mathrm{NaOCl}$ appears to be suitable for endodontic irrigation, it does not alter the inorganic content of the radicular dentin and does not remove the smear layer that is formed in the root canal walls after the canal is prepared (3). Demineralizing agents such as ethylenediaminetetraaceticacid (EDTA) have been recommended as adjuvants in root canal therapy (3). According to D'Arcangelo et al. (13), EDTA has limited potential to act on organic tissues. Pécora et al. (14) reported that the combination of $\mathrm{NaOCl}$ and EDTA enhanced dentin permeability. Furthermore, Saquy et al. (15) reported that the chelating ability of EDTA solutions was not modified when it was combined with $\mathrm{NaOCl}$.

Although many studies have investigated the separate dissolving potentials of $\mathrm{NaOCl}$ and EDTA, there is no report regarding the effect of combining these two agents in dissolving pulp tissue. Therefore, the aim of the present study was to evaluate the tissue dissolving ability of several various concentrations of sodium hypochlorite either alone or combined with $17 \%$ EDTA.

\section{Methods}

The present study was approved by the Research Board and to the Ethics Committee in Research at the University of Passo Fundo (Passo Fundo, RS, Brazil).

The sodium hypochlorite solutions (Farmácia Marcela, Porto Alegre, RS, Brazil) were manufactured 1 week prior to the experiment. The chloride concentration was confirmed by titration analysis performed at the College of Pharmaceutical Sciences, University of Caxias do Sul, Porto Alegre, RS, Brazil.

Forty central and lateral incisors were extracted from the upper arches of 2-year-old bovine immediately before the experiment. The roots were scaled with curettes, and the tissues were removed with surgical blades. Two grooves were cut in the buccal and palatine surfaces of each tooth, without reaching the pulp chamber, using a low-speed diamond-covered disc (Microdent, Ribeirão Preto, SP, Brazil). The tooth was split by inserting a chisel into the grooves.
The entire pulp tissue was carefully removed from the root canal and placed over a filter paper. The tissue was divided into $9-10-\mathrm{mm}$ fragments, and their weight was determined in a precision balance (Bioprecisa FA-2104N, São Paulo, SP, Brazil). The specimen was then transferred to a plastic vial.

The test groups comprised 10 samples and corresponded to the substance that was used for the pulp dissolution assay as described in Table 1. The pulp samples were exposed to $10 \mathrm{~mL}$ of each substance/mixture. For the combined $\mathrm{NaOCl}+$ EDTA solutions, $5 \mathrm{~mL}$ of each substance was mixed by vortexing at $23^{\circ} \mathrm{C}$.

Table 1. The substances tested in the experiment.

\begin{tabular}{|c|c|c|}
\hline Group & Substance/Mixture & $\begin{array}{c}\text { Sample size } \\
(\mathrm{n})\end{array}$ \\
\hline G1 & Saline Solution (10 mL) & 10 \\
\hline G2 & $0.5 \% \mathrm{NaOCl}$ Solution (10 mL) & 10 \\
\hline G3 & 1.0\% NaOCl Solution (10 mL) & 10 \\
\hline G4 & 2.5\% NaOCl Solution (10 mL) & 10 \\
\hline G5 & 17\% EDTA Solution (10 mL) & 10 \\
\hline G6 & $\begin{array}{l}0.5 \% \mathrm{NaOCl} \text { Solution }(5 \mathrm{~mL})+ \\
17 \% \text { EDTA Solution }(5 \mathrm{~mL})\end{array}$ & 10 \\
\hline G7 & $\begin{array}{l}\text { 1.0\% NaOCI Solution }(5 \mathrm{~mL})+ \\
17 \% \text { EDTA Solution }(5 \mathrm{~mL})\end{array}$ & 10 \\
\hline G8 & $\begin{array}{l}2.5 \% \mathrm{NaOCl} \text { Solution }(5 \mathrm{~mL})+ \\
17 \% \text { EDTA Solution }(5 \mathrm{~mL})\end{array}$ & 10 \\
\hline
\end{tabular}

The pulp fragments were immersed in the respective solution/mixture for a 2-hour period. The fragments were then removed and placed over a filter paper for $3 \mathrm{~min}$ to remove any excess moisture. The final sample weight was measured in the precision balance. The difference between the initial and final weights was used to calculate the weight loss, thereby representing the dissolving ability of each substance/mixture.

Statistical analyses were performed using PASW Statistics 18.0 (SPSS Inc., Chicago, IL, USA). A Student's $t$-test for paired samples was used to compare the sample weights before and after immersion in each substance. An ANOVA followed by a Tukey's Test was used to compare the dissolving ability of the various substances or mixtures.

\section{Results}

The mean and standard deviation values for the pulp tissue weights before and after the dissolving test are shown in Table 2. There was a significant difference between the sample weight before and after treatment for the following groups: G2, G3, G4, G5, G6, G7 and G8 $(P<0.05$, $t$-test for paired samples). The $2.5 \%$ sodium hypochlorite solution completely dissolved the pulp tissue within the test period.

The reduction in pulp tissue weight in each of the tested groups is shown in Table 3. Regardless of the concentration of $\mathrm{NaOCl}$, when EDTA was combined with the $\mathrm{NaOCl}$, 
the resulting combination was less effective than sodium hypochlorite alone in dissolving pulp tissue $(P<0.05$, ANOVA and Tukey's test). The $2.5 \% \mathrm{NaOCl}+$ EDTA solution caused the highest amount of tissue dissolution of all of the EDTA/ $\mathrm{NaOCl}$ mixtures. EDTA alone did not markedly dissolve the pulp tissue. There was no statistical difference among the groups that were treated with $0.5 \% \mathrm{NaOCl}+\mathrm{EDTA}, 1.0 \%$ $\mathrm{NaOCl}+\mathrm{EDTA}$, EDTA alone, and saline.

Table 2. Mean and standard deviation values for the pulp tissue weight (in $\mathrm{mg}$ ) before and after the dissolving test.

\begin{tabular}{lcc}
\hline & \multicolumn{1}{c}{ Before $^{*}$} & After $^{*}$ \\
\hline Saline Solution & $26.75( \pm 3.31)^{\mathrm{B}}$ & $25.76( \pm 3.19)^{\mathrm{B}}$ \\
$0.5 \% \mathrm{NaOCl}$ & $28.71( \pm 4.48)^{\mathrm{B}}$ & $13.38( \pm 5.14)^{\mathrm{A}}$ \\
$1.0 \% \mathrm{NaOCl}$ & $27.29( \pm 2.84)^{\mathrm{B}}$ & $3.65( \pm 3.89)^{\mathrm{A}}$ \\
$2.5 \% \mathrm{NaOCl}$ & $28.37( \pm 3.42)^{\mathrm{B}}$ & $0^{\mathrm{A}}$ \\
$17 \% \mathrm{EDTA}$ & $27.79( \pm 3.49)^{\mathrm{B}}$ & $26.41( \pm 3.56)^{\mathrm{A}}$ \\
$0.5 \% \mathrm{NaOCl}+$ EDTA & $25.96( \pm 4.45)^{\mathrm{B}}$ & $23.43( \pm 3.68)^{\mathrm{A}}$ \\
$1.0 \% \mathrm{NaOCl}+$ EDTA & $25.96( \pm 4.41)^{\mathrm{B}}$ & $21.87( \pm 4.74)^{\mathrm{A}}$ \\
$2.5 \% \mathrm{NaOCl}+$ EDTA & $29.07( \pm 3.32)^{\mathrm{B}}$ & $22.85( \pm 4.18)^{\mathrm{A}}$ \\
\hline
\end{tabular}

* Different uppercase letters in the same line represent statistical difference between groups ( $\alpha=0.05$, t-test for paired samples).

Table 3. Mean and standard deviation tissue dissolution values (expressed in absolute weight loss and as a percentage) after exposure to the indicated solutions.

\begin{tabular}{lccc}
\hline & $\begin{array}{c}\text { Weight reduction } \\
(\mathbf{m g})\end{array}$ & $\%$ reduction & $*$ \\
\hline Saline Solution & $0.99 \pm 0.36$ & 3.70 & $\mathrm{E}$ \\
$0.5 \% \mathrm{NaOCl}$ & $15.33 \pm 4.26$ & 53.40 & $\mathrm{C}$ \\
$1.0 \% \mathrm{NaOCl}$ & $23.64 \pm 4.08$ & 86.63 & $\mathrm{~B}$ \\
$2.5 \% \mathrm{NaOCl}$ & $28.37 \pm 3.42$ & 100.00 & $\mathrm{~A}$ \\
EDTA & $1.38 \pm 1.76$ & 4.97 & $\mathrm{E}$ \\
$0.5 \% \mathrm{NaOCl}+$ EDTA & $2.53 \pm 1.88$ & 9.75 & $\mathrm{DE}$ \\
$1.0 \% \mathrm{NaOCl}+$ EDTA & $4.09 \pm 2.12$ & 15.76 & $\mathrm{DE}$ \\
$2.5 \% \mathrm{NaOCl}+$ EDTA & $6.22 \pm 1.25$ & 21.40 & $\mathrm{D}$ \\
\hline
\end{tabular}

* The capital letters in the column represent statistical differences between the groups ( $\alpha=0.05$, ANOVA and Tukey's test).

\section{Discussion}

Although it is known that sodium hypochlorite can affect organic tissues, little is known with regard to its dissolving ability when combined with other auxiliary chemical substances. We used an in vitro protocol that allowed us to compare the ability of $\mathrm{NaOCl}$ and $\mathrm{NaOCl}+$ EDTA to dissolve bovine pulp tissue.

During endodontic treatment, the solvent action of sodium hypochlorite is a desirable, as this can remove the pulp tissue remnants. Various experimental models have been tested to determine the dissolving effect of sodium hypochlorite solutions (9-10,16-17). These methods assessed the weight loss of the sample $(9-10,18)$, the time to dissolution (19-20), or provided data for microscopic examination (16) and a visual assessment of the size of the remaining tissue (21). Both pulp weight loss and the time to sample dissolution provide results that can be quantified, thereby allowing a more reliable analysis and minimizing any intrinsic bias.

Tissue dissolution depends on the frequency of agitation, the amount of organic tissue in relation to the amount of $\mathrm{NaOCl}$ and the surface area of the sample that is being dissolved (18). Several studies did not report whether the solutions were agitated or not $(10,17)$. In the present study, we used no mechanical agitation to allow the measurement of only the intrinsic ability of each solution to dissolve the tissue. Furthermore, each sample was immersed in the same volume of $\mathrm{NaOCl}$ or $\mathrm{NaOCl}+\mathrm{EDTA}$. Organic tissues, such as human pulp (16), rabbit liver (18), rat tongue (9), and porcine palatal mucosa (10), have been used in dissolution assays in endodontics. Koskinen et al. (22) reported that bovine pulp tissue is similar to human pulp tissue. Moreover, it can be easily isolated from bovine teeth, providing an adequate amount of tissue testing and allowing standardization of the weight and length of each sample. In the present study, the pulp samples were of similar weight (with a mean weight of $27.49 \pm 1.20 \mathrm{mg}$ ) and length.

In the present study, the $\mathrm{NaOCl}$ solutions dissolved the pulp tissue in a concentration-dependent manner. The smallest degree of dissolution was observed with the $0.5 \%$ $\mathrm{NaOCl}$ solution, which is similar to a previous report by Türkün and Cengiz (23). Therefore, an increase in the tissue dissolving ability of low-strength $\mathrm{NaOCl}$ solutions might be achieved by frequently changing the irrigation solution (20) or by using a larger volume (18). The present study found that only the $2.5 \% \mathrm{NaOCl}$ solution completely dissolved the samples within 2 hours. Koskinen et al. (22) reported that $2.5 \% \mathrm{NaOCl}$ was twice as effective as $0.5 \% \mathrm{NaOCl}$. The results demonstrate the proteolytic activity of $\mathrm{NaOCl}$ solutions in bovine pulp tissue. Additional studies should be performed to determine the clinical impact of this effect on the tissue remnants, particularly inside the root canal system, where diffusion and the amount of solution that can reach irregularities tend to be reduced.

The tissue solubility of $17 \%$ EDTA was similar to saline solution. D'Arcangelo et al. (13) also reported low values for tissue dissolution when pulp fragments were exposed to EDTA for various time periods. In the present study, the small difference that was observed in sample weight before and after the immersion period might be associated with removing the excess liquid after the test rather than the intrinsic solving activity of the irrigant. Several studies support the notion that EDTA acts on the inorganic matrix of the root canal and also enhances removal of the smear layer by chelating calcium ions (22).

An alternating irrigation regimen with $\mathrm{NaOCl}$ and EDTA may be a reasonable approach to complement the mechanical action of the instruments during preparation of the root canal system, as each substance can act on a different substrate 
(i.e., the organic tissues and/or inorganic matrices). Such a protocol is often used to reduce the presence of the smear layer in the root canal walls (24). Irrigating the root canal with a mixture of $\mathrm{NaOCl}$ and EDTA in varying proportions was suggested by Pécora et al. (14) and Saquy et al. (15). Irala et al. (25) measured the time that was required for the complete dissolution of pulp fragments and found that $\mathrm{NaOCl}+$ EDTA did not completely dissolve the tissue fragments. In the present study, we measured the reduction in weight following the immersion period, which provided more reliable data regarding the dissolving properties of both $\mathrm{NaOCl}$ solution and combined $\mathrm{NaOCl}+17 \%$ EDTA solutions. As stated above, low-concentration $\mathrm{NaOCl}$ solutions have a limited ability to dissolve pulp tissue. It is possible that combining these solutions decreased the final chloride concentration and/or the solution's $\mathrm{pH}$, both of which are important chemical properties that are associated with the ability to dissolve tissue.

In summary, the present study suggests that the combined use of $\mathrm{NaOCl}+\mathrm{EDTA}$ reduces the tissue-dissolving properties of $\mathrm{NaOCl}$, regardless the initial concentration of $\mathrm{NaOCl}$. Further studies should be conducted to assess the antimicrobial and chemical properties of the combined solution. root canal geometry assessed by micro computed tomography. Int Endod J 2001;34: 221-30.

2. Byström A, Sundqvist G. Bacteriologic evaluation of the effect of 0.5 percent sodium hypochlorite in endodontic therapy. Oral Surg Oral Med Oral Pathol 1983;55:307-12.

3. Zehnder M. Root canal irrigants. J Endod 2006;32:389-98.

4. Gambarini G, De Luca M, Gerosa R. Chemical stability of heated sodium hypochlorite endodontic irrigants. J Endod 1998;24:432-4.

5. Vianna ME, Gomes BP, Berber VB, Zaia AA, Ferraz CC, de Souza-Filho FJ. In vitro evaluation of the antimicrobial activity of chlorhexidine and sodium hypochlorite. Oral Surg Oral Med Oral Pathol Oral Radiol Endod 2004;97:79-84.

6. Andersen M, Lund A, Andreasen JO, Andreasen FM. In vitro solubility of human pulp tissue in calcium hydroxide and sodium hypochlorite. Endod Dent Traumatol 1992;8: 104-8.

7. Vianna ME, Horz HP, Gomes BP, Conrads G. In vivo evaluation of microbial reduction after chemo-mechanical preparation of human root canals containing necrotic pulp tissue. Int Endod J 2006;39:484-92.

8. Gomes BP, Martinho FC, Vianna ME. Comparison of $2.5 \%$ sodium hypochlorite and $2 \%$ chlorhexidine gel on oral bacterial lipopolysaccharide reduction from primarily infected root canals. J Endod 2009;35:1350-3.

9. Só MVR, Cemim A, Pereira EP, Irala LED. Tissue dissolution ability of sodium hypochlorite from different manufacturers. Braz Endod J 1997;2:33-5.

10. Naenni N, Thoma K, Zehnder M. Soft Tissue dissolution capacity of currently used and potential endodontic irrigants. J Endod 2004;30:785-7.

11. Spanó JC, Barbin EL, Santos TC, Guimarães LF, Pécora JD. Solvent action of sodium hypochlorite on bovine pulp and physico-chemical properties of resulting liquid. Braz Dent J 2001;12:154-7.

12. Okino LA, Siqueira EL, Santos M, Bombana AC, Figueiredo JA. Dissolution of pulp tissue by aqueous solution of chlorhexidine digluconate and chlorhexidine digluconate gel. Int Endod J 2004:37:38-41

13. D’Arcangelo C, Di Nardo Di Maio CF, Stracci N, Spoto G, Malagnino VA, Caputi S. Pulpdissolving ability of several endodontic irrigants: a spectrophotometric evaluation. Int J Immunopathol Pharmacol 2007;20:381-6.

14. Pécora JD, Neto MDS, Saquy PC, Silva RG, Cruz Filho AM. Effect of Dakin's and EDTA solutions on dentin permeability of root canals. Braz Dent J 1993;4:79-84.

15. Saquy PC, Maia Campos G, Sousa Neto MD, Guimarães LF, Pécora JD. Evaluation of chelating action of EDTA in association with Dakin's solution. Braz Dent J 1994;5: 65-70.

16. Senia ES, Marshall FJ, Rosen S. The solvent action of sodium hypochlorite on pulp tissue of extracted teeth. Oral Surg Oral Med Oral Pathol 1971;31:96-103.

17. Nakamura $H$, Asai $K$, Fujita $H$, Nakazato $H$, Nishimura $Y$, Furuse $Y$, Sahashi E. The solvent action of sodium hypochlorite on bovine tendon collagen, bovine pulp, and bovine gingiva. Oral Surg Oral Med Oral Pathol 1985;60:322-6.

18. Moorer WR, Wesselink PR. Factors promoting the tissue dissolving capability of sodium hypochlorite. Int Endod J 1982;15:187-96.

19. Johnson BR, Remeikis NA. Effective shelf-life of prepared sodium hypochlorite solution. J Endod 1993;19:40-3. 
20. Hasselgren G, Olsson B, Crek M. Effects of calcium hydroxide and sodium hypochlorite on the dissolution of necrotic porcine muscle tissue. J Endod 1988; 14:125-7.

21. Thé SD. The solvent action of sodium hypochlorite on fixed and unfixed necrotic tissue. Oral Surg Oral Med Oral Pathol 1979;47:558-61.

22. Koskinen KP, Meurman JH, Stenvall H. Appearance of chemically treated root canal walls in the scanning electron microscope. Scand J Dent Res 1980;88:397-405.

23. Türkün M, Cengiz T. The effects of sodium hypochlorite and calcium hydroxide on tissue dissolution and root canal cleanliness. Int Endod J 1997;30:335-42.

24. Guerisoli DM, Marchesan MA, Walmsley AD, Lumley PJ, Pecora JD. Evaluation of smear layer removal by EDTAC and sodium hypochlorite with ultrasonic agitation. Int Endod J 2002;35:418-21.

25. Irala LE, Grazziotin-Soares R, Salles AA, Munari AZ, Pereira JS. Dissolution of bovine pulp tissue in solutions consisting of varying $\mathrm{NaOCl}$ concentrations and combined with EDTA. Braz Oral Res 2010;24:271-6. 